\title{
Revegetation of Oil Well Reserve Pits in West Texas
}

MARK L. MCFARLAND, DARRELL N. UECKERT, AND STEVE HARTMANN

\section{Abstract}

On-site disposal of drilling fuids frequently causes severe, longterm disturbance of rangeland soils. The efiects of mulch on establishment and standing erops of seeded kochia [Kochia scoporia (L.) Schrad.] King Ranch bluestem [Bothriochloa ischaemum (L.) Kengb Lehmann lovegrass (Eragrostis Lhmannima Nees), kleingrass 'Selection 75' (Panicum coloratum L.), alkali sacaton [Sporobolus atroides (Torr.) Torr.], and fourving saltbush [Atriplex canescens (Pursh) Nutt] and transplanted fourwing saltbush were evaluated on 4, recently covered oil well reserve pits in Reagan County Texas, in 1981 and 1982. On-site disposal of drilling fluids resulted in subatantial to large increases in sodium adsorption ratios (SAR) and concentrations of soluble salts, primarily sodium chloride, in reserve pit soils. Mulching with $4,500 \mathrm{~kg} / \mathrm{ha}$ of weathered hay had no effect, but irrigation was essential for establishment and growth of the seeded species on severely contaminnted soils (EC. 71 to $114 \mathrm{dS} \mathrm{m}^{-1}, \mathrm{SAR} 33$ to 127). Mulching improved establishment and yields of seeded King Ranch bluestem and kleingrass on reserve pit soils with EC. values of 9 to $11 \mathrm{dS} \mathrm{m}^{-1}$ and SAR values of 12 to 16 . Application of $5.1 \mathrm{~cm}$ of supplemental water and mulching reserve pit soils with EC. values of 3 to 7 and SAR values of 5 to 9 stimulated establishment of competing vegetation, which tended to decrease establishment and yields of seeded and transplanted species. Establishment and yields of transplanted fourwing saltbush were acceptable with or without mulching or irrigation. Survival of fourwing saltbush transplants was near $100 \%$ on moderately contaminated soils and 26 to $30 \%$ on severely contaminated soils.

Key Words: reclamation, salinity, mulch, rangeland seeding, shrubs

Activities associated with oil and natural gas exploration and production seriously damage large acreages of arid and semiarid rangeland in west Texas. Construction of drilling sites, oil field roads, installation of pipelines, and on-site disposal of drilling fluids reduce forage and browse production, increase susceptibility of soils to erosion, and frequently result in persistent stands of undesirable plants. Oil and gas production activities have caused soil salinity problems on about 174,000 ha of land in Texas (Carl Gray, Texas State Soil and Water Conservation Board, Temple, Texas, unpublished data).

Most oil and gas wells in west Texas are drilled by the rotary method. Typical drilling fluids or muds contain $5 \%$ bentonite in fresh water or brine, with sodium hydroxide $(\mathrm{NaOH})$ added as a dispersant, lignite or lignosulfonate to stabilize the slurry, and a density increasing material, usually barite $\left(\mathrm{BaSO}_{4}\right)$ (Simpson 1975). Quantity and chemical composition of drilling fluids vary with location, depth of drilling, and the individual drilling program.

Reserve pits (earthen basins) about $1 \mathrm{~m}$ deep are used for handling, storage, and final disposal of drilling fluids. The fluid, cuttings, and waste materials produced during drilling are usually left in the reserve pit when drilling is completed, allowed to dry and then covered with soil from the pit borders. The soil and drilling residues are often mixed to disperse high concentrations of chemi-

\footnotetext{
Authors are research assistant, University Lands Surface Interest, the University of Texas System, Midland 79702; professor, Texas Agricultural Experiment Station, 7887 N. Hwy. 87, San Angelo 76901 ; and manager, University I ands Surface Interest, the University of Texas System, Midland 79702.

This article is approved by the Director, Texas Agricultural Experiment Station, as TA No. 20850.

This research was a cooperative effort between University Lands, University of Texas System, and the Texas Agricultural Experiment Station, Texas A\&M University System.

Manuscript accepted 28 August 1986.
}

cals. Normal disposal rates of 10 drilling fluid components caused significant growth reductions of beans (Phaselous vulgaris L.) and corn [Zea mays var. saccharata (Sturtev.) Bailey] (Miller et al. 1980). Both organic and inorganic constituents were identified as potential contaminants. High levels of soluble salts or high exchangeable sodium percentages produced by sodium dichromate $\left(\mathrm{Na}_{2} \mathrm{Cr}_{2} \mathrm{O}_{7} \cdot 2 \mathrm{H}_{2} \mathrm{O}\right)$, potassium chloride $(\mathrm{KCl})$, and sodium hydroxide (NaOH) were primary causes of reduced plant growth in 1:1 and 1:4 (v:v) drilling fluid: soil mixtures (Miller and Pesaran 1980). Plant uptake of $\mathrm{Zn}, \mathrm{Cu}, \mathrm{Cd}, \mathrm{Pb}$, and $\mathrm{As}$ was directly related to the concentrations of these trace elements added to soils by drilling fluids (Nelson et al. 1984). However, low $\mathrm{pH}$ values $(<4.0$ ) sufficient to result in significant release to trace elements from drilling fluids are unlikely due to their great neutralizing capacity (Deeley and Canter 1986).

Authority to regulate the disposal of drilling fluid wastes in Texas is held by the Texas Railroad Commission. Accepted disposal methods include landfarming and burial (Statewide Rule 8). On-site disposal of drilling fluids is the common and preferred procedure. However, secondary succession on these sites in arid and semiarid regions is extremely slow due to low precipitation, soil disturbance, and contamination. The relatively high sensitivity of many range grasses to salinity has been reported (Dubetz et al. 1959, Tadmor et al. 1969). Screening potentially useful materials in the field is of critical importance (O'Leary 1984). Controversy over use of native vs. introduced species for disturbed land revegetation has given way to selection of adapted plant materials (Plummer 1977). The effective use of limited supplemental irrigation for establishment of grasses and shrubs on salt-affected soils has been documented (Ries 1980, Dollhopf and Depuit 1981). Straw and other natural mulches usually prevent crusting of the soil surface and reduce soil temperatures, evaporation, and runoff (Adams 1966, Springfield 1972). Mulching may also reduce salinity by reducing evaporation and subsequent salt accumulation at the soil surface (Fanning and Carter 1963, Hamilton 1972). Mulch, fertilizer, gypsum, and various physical amendments enhanced establishment of several shrubs on saline-alkali (EC. $9.2 \mathrm{dS} \mathrm{m}^{-1}$, SAR 33.1) bentonite mine spoils (Uresk and Yamamoto 1986).

Reclamation of oil well reserve pits is a major concern to land owners, energy firms, and resource management agencies. The objective of this study was to evaluate selected plant materials and mulching for returning these areas to acceptable levels of productivity.

\section{Study Areas}

The study was conducted in the western Edwards Plateau resource area on land owned by the University of Texas System in Reagan County, near Big Lake, Texas. The climate is semiarid, with hot summers and cold, dry winters. Annual precipitation averages $43 \mathrm{~cm}$, approximately $78 \%$ of which occurs from May to October. Much of the warm-season rainfall occurs from localized convection showers and thunderstorms. The average daily maximum temperature in July is $35.5^{\circ} \mathrm{C}$, and the average frost-free period is 229 days (Blum 1977).

Two experiments were established on oil well reserve pits about $10 \mathrm{~km}$ east of Big Lake (Ferguson sites) in the spring of 1981, and 2 experiments were established on reserve pits $32 \mathrm{~km}$ west of Big Lake (Jackson sites) in the spring of 1982. Soils were Reagan silty clay loams (fine-silty, mixed, thermic family of Ustollic Calciorthids). Dominant grasses on rangeland adjacent to the study sites were buffalograss [Buchloe dactyloides (Nutt.) Engelm.], burro- 
grass (Scleropogon brevifolius Phil.), and tobosa [Hilaria mutica (Buckl.) Benth.]. Major forbs included broom snakeweed [Xanthocephalum sarothrae (Pursh) Shinners], desertholly (Perezia nana Gray), and leatherweed croton [Croton pottsii (Klotzsch) Muell. Arg.]. Honey mesquite (Prosopis glandulosa var. glandulosa Torr.) was the primary woody species at the Ferguson sites, whereas creosotebush [Larrea tridentata (DC.) Cov.] and tarbush (Flourensia cernua DC.) were the dominate shrubs at the Jackson sites.

\section{Methods}

Species evaluated were King Ranch bluestem [Bothriochloa ischaemum (L.) Keng], Lehmann lovegrass (Eragrostis lehmanniana Nees), kleingrass 'Selection 75' (Panicum coloratum L.), alkali sacaton [Sporobolus airoides (Torr.) Torr.], kochia [Kochia scoparia (L.) Schrad.], and fourwing saltbush [Atriplex canescens (Pursh) Nutt.]. Fourwing saltbush seeds were harvested in November 1980 from a native stand at Texon, Texas, $17 \mathrm{~km}$ west of Big Lake and dewinged in a modified hammermill (Springfield 1964). Fourwing saltbush seedlings were grown in 4 by 5 by $18-\mathrm{cm}$ polyethylene containers in a peat moss/vermiculite/silty clay loam soil mixture ( $2: 1: 1$ by volume) in a greenhouse for about 3 months prior to transplanting. Transplants were pruned to $10 \mathrm{~cm}$ prior to planting to reduce initial moisture stress. Grass and kochia seeds were purchased from commercial sources.

Each reserve pit was covered 1 month prior to seedbed preparation by the standard procedure with a crawler-tractor, then disked and fenced to exclude livestock, white-tailed deer (Odocoileus virginiana Zimmerman), and lagomorphs. Each site was divided into 6 blocks containing $6.1-$ by $6.1-\mathrm{m}$ plots and the following treatments were randomly assigned within each block:

1. King Ranch bluestem seeded at $3.4 \mathrm{~kg}$ pure live seed (P.L.S.)/ha;

2. Kleingrass seeded at $2.2 \mathrm{~kg}$ P.L.S. / ha;

3. Lehmann lovegrass seeded at $1.1 \mathrm{~kg}$ P.L.S./ha;
4. Alkali sacaton seeded at $1.1 \mathrm{~kg}$ P.L.S./ha (Jackson sites only);

5. Kochia seeded at $2.2 \mathrm{~kg}$ P.L.S./ha;

6. Fourwing saltbush seeded at $13.9 \mathrm{~kg}$ P.L.S./ha; and,

7. Fourwing saltbush seedlings transplanted on 0.9 -m centers (36 transplants per plot).

Experimental design was a randomized complete block arranged as a split-block with 3 replications. Planting dates were 28 April 1981 at the Ferguson sites and 17 March 1982 at the Jackson sites. Seeds were broadcast onto freshly disced soil with a hand spreader and cultipacked twice. Forage sorghum (Ferguson sites) or wheat straw (Jackson sites) mulch (main plot effect) was applied at 4,500 $\mathrm{kg} /$ ha after seeding to half the blocks on each reserve pit. One reserve pit at each location was sprinkler irrigated for 1 to 2 months after planting to facilitate seedling emergence. A total of $5.1 \mathrm{~cm}$ of irrigation was applied at the rate of $0.6 \mathrm{~cm} / \mathrm{hr}$ on 4 dates between 13 May and 28 May 1981 at the Ferguson site, while a total of 18.4 cm was applied on 13 days between 12 May and 9 July 1982 at the Jackson site. The other reserve pit at each location received no irrigation.

Soil samples were collected from 0 to $15-, 15$ to 30 -, and 30 to $45-\mathrm{cm}$ depths at the time of planting from 12 locations arranged on a grid system within each reserve pit and from adjacent undisturbed areas outside the plots.

Samples were air dried and pulverized to pass a $2-\mathrm{mm}$ sieve and analyzed by the Texas Agricultural Extension Service Soil Testing Laboratory for soluble cations $(\mathrm{Ca}, \mathrm{Mg}, \mathrm{K}, \mathrm{Na})$ and anions $\left(\mathrm{SO}_{4}\right.$, $\mathrm{Cl}$ ), electrical conductivity (EC.), and $\mathrm{pH}$ (Welch et al. 1980) using extracts from the saturated paste (U.S. Salinity Lab. Staff 1954).

Seedlings were counted in 10 , equidistantly spaced, $0.25-\mathrm{m}^{2}$ quadrats in each plot 2 months after planting. Seedlings were also counted 6 and 16 months after planting at the Ferguson sites, and 7 months after planting at the Jackson sites using the same procedure. Standing crops were estimated 6 and 16 months after plant-

Table 1. Mean soluble cation and anion concentrations (meq $\mathrm{L}^{-1}$ ), pH, electrical conductivities (dS $\mathrm{m}^{-1}$ ), and sodium adsorption ratios at 3 depths on oil well reserve pits and adjacent undisturbed areas near Bis Lake, Texas. 1

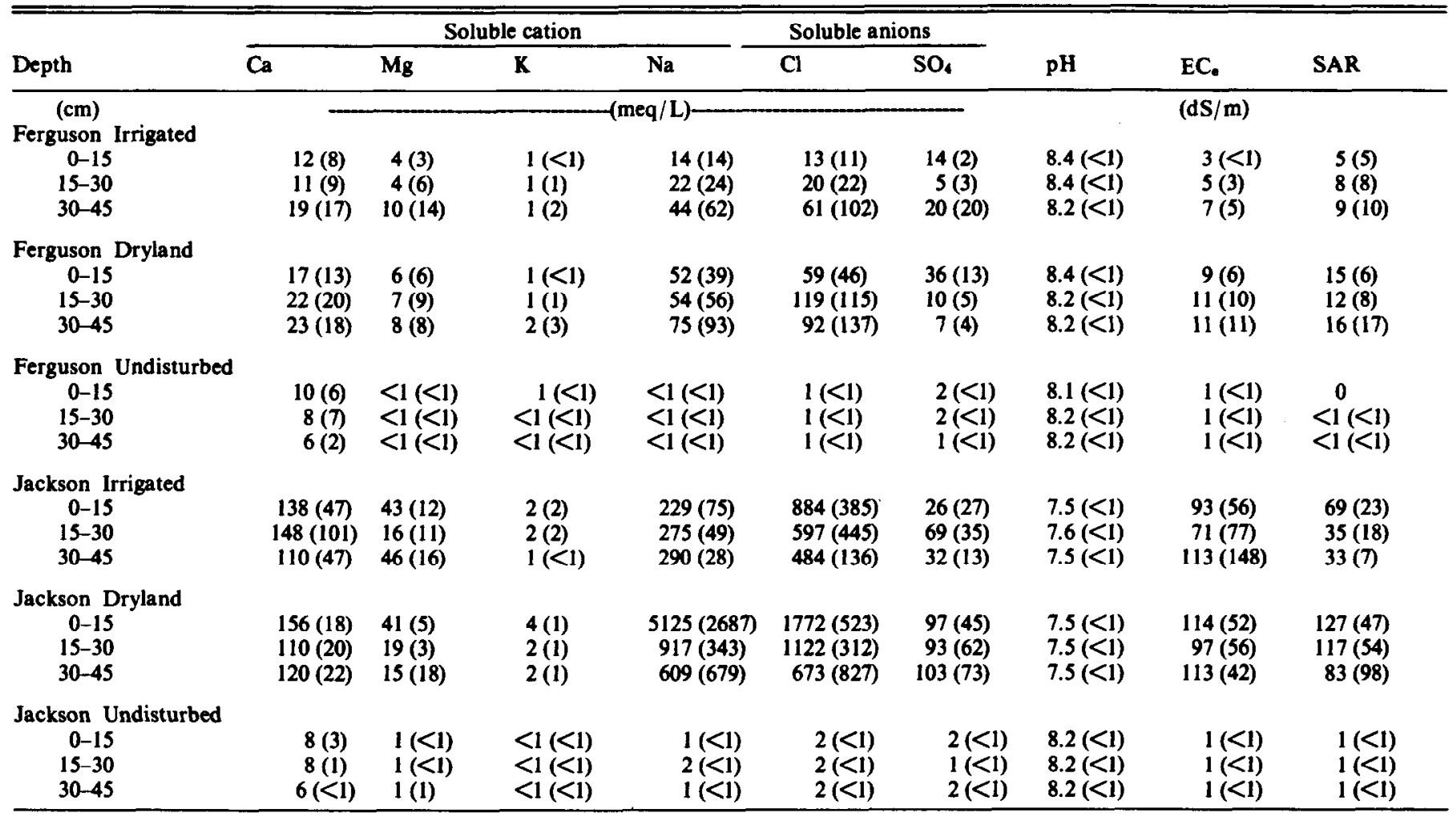

${ }^{1}$ Values in parentheses are the standard deviations for the respective means. 
ing at the Ferguson sites and 7 months after planting at the Jackson sites by harvesting to ground line within 10 , equidistantly spaced, $0.25-\mathrm{m}^{2}$ quadrats in each plot. Six transplanted fourwing saltbush plants were harvested for estimating standing crop in each plot receiving the transplant treatment. Samples were oven dried at $60^{\circ}$ $\mathrm{C}$ to a constant weight. Canopy heights of all live fourwing saltbush transplants and 25 fourwing saltbush seedlings in each seeded plot were measured 6 and 16 months after planting at the Ferguson sites.

Treatment effects on stand densities, standing crops, and fourwing saltbush canopy heights were determined using analyses of variance. Means were separated where appropriate with Tukey's $w$-procedure (Steele and Torrie 1960).

\section{Results and Discussion}

Drilling fluids severely altered several chemical properties of oil well reserve pit soils (Table 1). The extent of soil contamination varied greatly among locations, reflecting differences in individual drilling operations. Soil chemical properties also varied greatly among samples collected within each reserve pit, indicating that current reserve pit closure procedures do not effectively disperse high chemical concentrations. Concentrations of most soluble cations and anions were greatly increased in reserve pit soils at the Jackson sites, compared to those in adjacent, undisturbed soils, whereas changes at the Ferguson sites were substantial but less dramatic. Sodium and chloride were the predominant ions in reserve pit soils. Soluble salt concentrations in the surface $15 \mathrm{~cm}$ at the time of planting averaged 93 and $114 \mathrm{dS} \mathrm{m}^{-1}$ on the Jackson irrigated and dryland sites, respectively, and 3 and $9 \mathrm{dS} \mathrm{m}^{-1}$ on the Ferguson irrigated and dryland sites, respectively, compared to about $1 \mathrm{dS} \mathrm{m}^{-1}$ in adjacent, undisturbed soils. Concentrations of soluble salts at the Ferguson sites increased with depth and concentrations in the surface $15 \mathrm{~cm}$ increased 2- to 3-fold during the 16-month period after planting (McFarland 1984). Soluble salt concentrations in soils at the Jackson sites changed little during the year after planting. The salt concentrations at time of planting corresponded to osmotic potentials of -1 to $-4 \mathrm{MPa}$ at the Ferguson sites and lower than $-11 \mathrm{MPa}$ at the Jackson sites (U.S. Salinity Lab Staff 1954). Sodium adsorption ratios on reserve pit soils were substantially greater than those of undisturbed soils. Soil properties at the Jackson sites were characteristic of saline-alkali soils (U.S. Salinity Lab. Staff 1954).

\section{Ferguson Study Sites}

Applied water, $5.1 \mathrm{~cm}$, and rainfall resulted in a total of $30.1 \mathrm{~cm}$ of water on the irrigated site, compared to $31.6 \mathrm{~cm}$ of rainfall on the dryland site, during the period 1 May through 9 October 1981

Table 2. Monthly precipitation (cm) on oil well reserve pit study sites 10 $\mathrm{km}$ east and $32 \mathrm{~km}$ west of Big Lake, Texas.

\begin{tabular}{|c|c|c|c|c|}
\hline \multirow[b]{2}{*}{ Month } & \multicolumn{2}{|c|}{ Ferguson Study Sites } & \multicolumn{2}{|c|}{ Jackson Study Sites } \\
\hline & Irrigated & Dryland & Irrigated & Dryland \\
\hline & & $81-$ & -1 & 32 \\
\hline \multirow{3}{*}{$\begin{array}{l}\text { January } \\
\text { February } \\
\text { March }\end{array}$} & -1 & - & 0 & 0 \\
\hline & - & - & 0 & 0 \\
\hline & - & - & 0.9 & 0.9 \\
\hline April & - & - & 5.7 & 5.7 \\
\hline May & 12.1 & 12.9 & 4.4 & 4.4 \\
\hline June & 5.1 & 5.1 & 3.7 & 3.4 \\
\hline July & 0 & 0 & 0 & 0 \\
\hline August & 1.8 & 1.9 & 3.7 & 4.6 \\
\hline September & 1.8 & 7.4 & - & - \\
\hline October & 4.2 & 4.3 & - & - \\
\hline November & 9.6 & 10.5 & - & - \\
\hline December & 0 & 0 & - & - \\
\hline TOTAL & $\overline{34.6}$ & $\overline{42.1}$ & $\overline{18.4}$ & $\overline{19.0}$ \\
\hline
\end{tabular}

'Rainfall was not monitored at this time.
(Table 2). Rainfall in May was about $250 \%$ of the long-term average for the area. Precipitation during the 1982 growing season was slightly above the long-term average $(27.2 \mathrm{~cm})$, totaling 31.1 $\mathrm{cm}$ on the irrigated site and $32.9 \mathrm{~cm}$ on the dryland site for the period 1 January through 6 August 1982.

Mulching on the irrigated site did not affect seedling establishment (Table 3). Densities of kochia, King Ranch bluestem and

Table 3. Mean densities (plants $/ \mathrm{m}^{2}$ ) of 5 seeded species 2,6 and 16 months after planting on April 28, 1981 on an oil well reserve pit $10 \mathrm{~km}$ east of Big Lake, Texas (Ferguson Irrigated) as influenced by mulching."

\begin{tabular}{|c|c|c|c|}
\hline Species & Mulched & o Mulch & $\begin{array}{l}\text { Species } \\
\text { Means }\end{array}$ \\
\hline & \multicolumn{3}{|c|}{ - (plants $\left./ \mathrm{m}^{2}\right)$} \\
\hline Kochia & 78 & 57 & $68 a$ \\
\hline King Ranch bluestem & 56 & 57 & $56 a$ \\
\hline Lehmann lovegrass & 6 & 4 & $5 \mathrm{c}$ \\
\hline Kleingrass & 30 & 33 & $32 \mathrm{~b}$ \\
\hline \multirow[t]{2}{*}{ Fourwing saltbush } & 2 & 4 & $2 \mathrm{c}$ \\
\hline & \multicolumn{3}{|c|}{-6 months } \\
\hline Kochia & 27 & 8 & $18 \mathrm{a}$ \\
\hline King Ranch bluestem & 18 & 18 & $18 \mathrm{a}$ \\
\hline Lehmann lovegrass & 1 & 2 & $2 b$ \\
\hline Kleingrass & 16 & 14 & $15 \mathrm{a}$ \\
\hline \multirow[t]{2}{*}{ Fourwing saltbush } & 1 & 2 & $2 b$ \\
\hline & \multicolumn{3}{|c|}{-16 months- } \\
\hline Kochia & 2967 & 2160 & $2564 a$ \\
\hline King Ranch bluestem & 16 & 12 & $14 \mathrm{~b}$ \\
\hline Lehmann lovegrass & 4 & 2 & $3 \mathrm{~b}$ \\
\hline Kleingrass & 21 & 15 & $18 \mathrm{~b}$ \\
\hline Fourwing saltbush & 5 & 7 & $6 b$ \\
\hline
\end{tabular}

ISpecies means within an evaluation date followed by similar lower case letters are not significantly different at the $P \leq .05$ level according to Tukey's $w$-procedure. Mulching did not affect plant densities.

kleingrass were greater than those of Lehmann lovegrass and fourwing saltbush 2 months after planting. However, fourwing saltbush seedling densities averaged 2 and 4 plants $/ \mathrm{m}^{2}$ on mulched and unmulched plots, respectively, and were adequate stands. Seed from the Texon population of fourwing saltbush germinated under lower osmotic potentials than did seed from 3 other native populations in western Texas (Potter et al. 1986).

Densities of most seeded species had decreased 6 months after planting (Table 3). Insufficient root development because of readily available surface soil moisture on the irrigated site, may have contributed to increased seedling mortality (Madison and Hagan 1962). Irrigation may have reduced soluble salt concentrations near the soil surface sufficiently to enhance germination and emergence of the seeded species (Harbert and Berg 1974). However, capillary rise of soluble salts after irrigation ceased, concommitant with decreased rainfall amounts in June, July, and August (Table 2), may have resulted in increased moisture stress and greater seedling mortality (Fanning and Carter 1963). Competition from native forbs on irrigated plots may also have reduced survival of seedlings. Mean forb densities averaged $10( \pm 1)$ and $18( \pm 1)$ plants $/ \mathbf{m}^{2}$ on irrigated mulched and unmulched plots, respectively, during the first growing season. Competition from annual weeds substantially reduced growth and survival of fourwing saltbush and prostrate summer cypress [Kochia prostrata(L.) Shrad.] (Van Epps and McKell 1983).

Kochia densities on the irrigated site increased markedly during the second growing season (Table 3, 16-month evaluation) following seed production in 1981. Subsequent intraspecific competition decreased growth and yields of kochia (Table 4). Fourwing saltbush densities also increased in 1982, apparently from germination of dormant seeds. Dormancy may be an important survival mechanisms during periods of severe moisture stress caused by high salt concentrations in the soil (Shannon 1984). Densities of native forbs 
Table 4. Means standing crops (kg/ha) of selected species 6 and 16 months after planting on 28 April 1981 on an oil well reserve pit $10 \mathrm{~km}$ east of Big Lake, Texes (Ferguson Irrigated) as influenced by mulching and method of propagation.1

\begin{tabular}{|c|c|c|c|c|c|c|}
\hline \multirow[b]{2}{*}{ Propagation Method/Species } & \multicolumn{2}{|c|}{6 months } & \multirow[b]{2}{*}{ Mean } & \multicolumn{2}{|c|}{16 months } & \multirow[b]{2}{*}{ Mean } \\
\hline & Mulched & No Mulch & & Mulched & No Mulch & \\
\hline $\begin{array}{l}\text { Seeded } \\
\text { Kochia } \\
\text { King Ranch bluestem } \\
\text { Lehmann lovegrass } \\
\text { Kleingrass } \\
\text { Fourwing saltbush }\end{array}$ & $\begin{array}{r}10656 \\
272 \\
8 \\
236 \\
84\end{array}$ & $\begin{array}{r}14928 \\
960 \\
72 \\
1564 \\
692\end{array}$ & $\begin{array}{r}12792 \mathrm{a} \\
616 \mathrm{~b} \\
40 \mathrm{~b} \\
900 \mathrm{~b} \\
388 \mathrm{~b}\end{array}$ & $\begin{array}{r}7588 \\
732 \\
92 \\
3720 \\
7320\end{array}$ & $\begin{array}{r}10588 \\
264 \\
172 \\
5280 \\
22440\end{array}$ & $\begin{array}{c}9088 \mathrm{a}-\mathrm{c} \\
498 \mathrm{c} \\
132 \mathrm{c} \\
4500 \mathrm{bc} \\
14880 \mathrm{a}\end{array}$ \\
\hline $\begin{array}{l}\text { Transplanted } \\
\text { Fourwing saltbush } \\
\text { Treatment Mean }\end{array}$ & $\begin{array}{c}524 \\
1963 \mathrm{~b}\end{array}$ & $\begin{array}{l}2344 \\
3426 \text { a }\end{array}$ & $1434 \mathrm{~b}$ & $\begin{array}{l}9080 \\
4755 \text { b }\end{array}$ & $\begin{array}{l}18000 \\
9457 \mathrm{a}\end{array}$ & $13540 \mathrm{ab}$ \\
\hline
\end{tabular}

'Species means within a column and treatment means within a row followed by similar lower case letters are not significantly different at the $P \leq 05$ level according to Tukey's w-procedure.

were greater on irrigated plots 16 months after planting, averaging 31 and 43 plants $/ \mathrm{m}^{2}$ on irrigated mulched and unmulched plots, respectively, compared to 2 and 1 plants $/ \mathrm{m}^{2}$ on dryland mulched and unmulched plots, respectively.

Averaged across all species, mulch significantly decreased standing crops 6 and 16 months after planting on the irrigated site (Table 4). This was attributed to competition from volunteer forage sorghum which established from seed in the mulch and to competition from forbs. Gould et al. (1975) encountered similar problems with mulch while establishing native range plants on coal mine spoils in New Mexico. Incorporation of herbicides for weed control in mulches has been proposed (Springfield 1972), although use of "seed-free" mulching materials would likely be more cost effective.

Standing crops of kochia on the irrigated site were significantly greater than those of the other species 6 months after planting, averaging $12,792 \mathrm{~kg} / \mathrm{ha}$ (Table 4). The potential for rapid establishment of this annual species on severely disturbed, salt-affected soils in this region has been observed. Transplanted fourwing saltbush tended to have greater first-growing-season standing crops than that in seeded plots, but differences were not significant.

Standing crops of most species on the irrigated site increased during the 1982 growing season (Table 4, 16-month evaluation). Biomass production of seeded and transplanted fourwing saltbush tended to be greater than that of the other species, averaging 14,880 and $13,540 \mathrm{~kg} / \mathrm{ha}$, respectively. Canopy heights and standing crops of fourwing saltbush transplants were generally greater than those in plots in which the species established from seed, although differences were not significant. Average canopy heights were $103( \pm 12)$ $\mathrm{cm}$ for transplants compared to $87( \pm 7) \mathrm{cm}$ for plants established from seed. Survival of seeded and transplanted fourwing saltbush plants established in the first growing season was $100 \%$. Kleingrass was most productive of the 3 grass species, with standing crops averaging $4,500 \mathrm{~kg} / \mathrm{ha}$. Kochia standing crops after 16 months were lower than those in the first growing season. Poor vigor and chlorosis of kochia suggested that available soil nutrients may have been depleted due to heavy biomass production in 1981 .

Stand densities on the dryland study site exhibited a significant mulch $X$ species interaction 2,6 , and 16 months after planting (Table 5). Densities of King Ranch bluestem and kleingrass were significantly greater on mulched plots compared to unmulched plots on each evaulation date. A similar trend was observed for fourwing saltbush. Densities of most species had decreased 6 months after planting. Mean densities of competing forb species on dryland plots averaged $1<\mathrm{plant} / \mathrm{m}^{2}$ at the end of the first growing season. Kochia densities increased dramatically in the second growing season. In general, densities of the seeded species in most plots were sufficient to develop acceptable stands.

A significant mulch $X$ species interaction for standing crops was observed on both the 6 and 16 month evaluation dates (Table 6).
Table 5. Mean densities (plants/ $\mathrm{m}^{2}$ ) of 5 seeded species 2, 6 and 16 months after planting on 28 April 1981 on an oil well reserve pit $10 \mathrm{~km}$ east of Bis Lake, Teras (Ferguson Dryland) as influenced by mulching1.

\begin{tabular}{lcc}
\hline & Mulched & No Mulch \\
\hline Species & \multicolumn{2}{c}{ (plants $/ \mathrm{m}^{2}$ )- } \\
\hline & $21 \mathrm{a}-\mathrm{c}$ & $21 \mathrm{a}-\mathrm{c}$ \\
Kochia & $25 \mathrm{ab}$ & $4 \mathrm{c}$ \\
King Ranch bluestem & $2 \mathrm{c}$ & $6 \mathrm{bc}$ \\
Lehmann lovegrass & $36 \mathrm{a}$ & $2 \mathrm{c}$ \\
Kleingrass & $8 \mathrm{bc}$ & $2 \mathrm{c}$ \\
Fourwing saltbush & & \\
& $9 \mathrm{a}-\mathrm{c}$ & $15 \mathrm{bc}$ \\
Kochia & $20 \mathrm{ab}$ & $3 \mathrm{c}$ \\
King Ranch bluestem & $1 \mathrm{c}$ & $8 \mathrm{bc}$ \\
Lehmann lovegrass & $28 \mathrm{a}$ & $1 \mathrm{c}$ \\
Kleingrass & $8 \mathrm{bc}$ & $1 \mathrm{c}$ \\
Fourwing saltbush & & \\
& $2202 \mathrm{a}$ & $3880 \mathrm{a}$ \\
Kochia & $18 \mathrm{bc}$ & $2 \mathrm{~d}$ \\
King Ranch bluestem & $2 \mathrm{~d}$ & $5 \mathrm{~b}-\mathrm{d}$ \\
Lehmann lovegrass & $22 \mathrm{~b}$ & $3 \mathrm{~cd}$ \\
Kleingrass & $6 \mathrm{~b}-\mathrm{d}$ & $4 \mathrm{~cd}$ \\
\hline
\end{tabular}

1 Means within an evaluation date followed by similar lower case letters are not significantly different at the $P \leq .05$ level according to Tukey's $w$-procedure.

Table 6. Mean standing crops (kg/ha) of selected species 6 and 16 months after planting 28 April 1981 on an oil well reserve pit $10 \mathrm{~km}$ east of Bis Lake, Texas (Ferguson Dryland) as influenced by mulching and method of propagation.1

\begin{tabular}{|c|c|c|c|c|}
\hline \multirow[b]{2}{*}{ Propagation Method/Species } & \multicolumn{2}{|c|}{6 months } & \multicolumn{2}{|c|}{16 months } \\
\hline & Mulched & No Mulcl & h Mulched & No Mulch \\
\hline \multirow[b]{2}{*}{$\begin{array}{l}\text { Seeded } \\
\text { Kochia } \\
\text { King Ranch bluestem } \\
\text { Lehmann lovegrass } \\
\text { Kleingrass } \\
\text { Fourwing saltbush }\end{array}$} & & -1 & (g) (Ina) & \\
\hline & $\begin{array}{l}5396 \mathrm{~b} \\
1424 \mathrm{~cd} \\
1 \mathrm{~d} \\
4980 \mathrm{bc} \\
2328 \mathrm{~b}-\mathrm{d}\end{array}$ & $\begin{array}{r}10396 \mathrm{a} \\
156 \mathrm{~d} \\
248 \mathrm{~d} \\
96 \mathrm{~d} \\
1124 \mathrm{~d}\end{array}$ & $\begin{array}{c}6960 \mathrm{bc} \\
1908 \mathrm{c} \\
360 \mathrm{c} \\
13842 \mathrm{ab} \\
17468 \mathrm{ab}\end{array}$ & $\begin{array}{l}8652 \mathrm{ab} \\
108 \mathrm{~b} \\
3932 \mathrm{ab} \\
680 \mathrm{~b} \\
16748 \mathrm{ab}\end{array}$ \\
\hline $\begin{array}{l}\text { Transplanted } \\
\text { Fourwing saltbush }\end{array}$ & 3892 b-d & $2124 b-d$ & 24212 a & 20548 a \\
\hline
\end{tabular}

IMeans within an evaluation date followed by similar lower case letters are not significantly different at the $P \leq 05$ level according to Tukey's $w$-procedure. 
Standing crops of kochia on dryland unmulched plots were greater than those of the other species, averaging $10,396 \mathrm{~kg} / \mathrm{ha} 6$ months after planting. Mulching significantly, increased production of kleingrass and similar trends were evident for King Ranch bluestem and fourwing saltbush (seeded and transplanted). Kleingrass tended to produce the most uniform grass stands followed by King Ranch bluestem and Lehmann lovegrass.

Standing crops of most species on the dryland site increased in the second growing season (Table 6, 16-month evaluation). Significant interaction between mulch and species occurred due to the poor response of kochia and Lehmann lovegrass on mulched plots. Growth suppression of some species has been associated with the application of mulch (Stroh and Sundberg 1971, Behmer and McCalla 1963). High rates of mulch application may physically impair establishment of small-seeded species (Bieber 1969). Standing crops of seeded and transplanted fourwing saltbush tended to be greater than those of the other species. Canopy heights of seeded and transplanted fourwing saltbush averaged $91( \pm 19)$ and 119 $( \pm 11) \mathrm{cm}$, respectively, and survival of shrubs established by both propagation methods was near $100 \%$.

\section{Jackson Study Sites}

Precipitation on the Jackson study sites was only $79 \%$ of the long-term average during the first growing season (Table 2). Only $0.9 \mathrm{~cm}$ of rainfall was received during March 1982 (49\% of longterm average), the month in which the experiments were established. Irrigation water applied from 12 May through 9 July 1982 totaled $18.4 \mathrm{~cm}$. This resulted in a total of $36.8 \mathrm{~cm}$ of water on the irrigated site, compared to $19.0 \mathrm{~cm}$ of precipitation on the dryland site for the period of 17 March through 16 October 1982.

High concentrations of soluble salts in reserve pit soils at the Jackson sites (Table 1) seriously impaired seedling establishment. Mulching did not improve seedling establishment or standing crops of the seeded species on irrigated (Table 7) or dryland reserve

Table 7. Mean dendites (plants $/ \mathrm{m}^{2}$ ) and standing crops $(\mathrm{k} / \mathrm{ha}$ ) of selected species 7 months after planting on 17 March 1982 on an oil well reserve pit $32 \mathrm{~km}$ west of Big Lake, Texas (Jackson Irrigated) as influenced by mulching and method of propagation. 1

\begin{tabular}{|c|c|c|c|c|}
\hline \multirow[b]{2}{*}{ Propagation Method/Species } & \multicolumn{2}{|c|}{ Plant Density } & \multicolumn{2}{|c|}{ Standing Crop } \\
\hline & \multicolumn{2}{|c|}{ Mulched No Mulch } & \multicolumn{2}{|c|}{ Mulched No Mulch } \\
\hline & \multicolumn{2}{|c|}{$\ldots-\left(\right.$ plants $\left./ m^{2}\right)-\cdots$} & \multicolumn{2}{|c|}{$-(\mathrm{kg} / \mathrm{ha})$} \\
\hline \multicolumn{5}{|c|}{ (piants/104)- } \\
\hline Kochia & $\mathbf{0}$ & 0 & 0 & 0 \\
\hline King Ranch bluestem & 0 & 10 & $\mathbf{0}$ & 608 \\
\hline Lehmann lovegrass & 0 & 0 & 0 & 0 \\
\hline Kleingrass & 0 & 11 & $\mathbf{0}$ & 200 \\
\hline Alkali sacaton & 1 & 5 & 19 & 796 \\
\hline Fourwing saltbush & 1 & 2 & 39 & 864 \\
\hline \multicolumn{5}{|l|}{ Transplanted } \\
\hline Fourwing saltbush & - & - & 206 & 1891 \\
\hline
\end{tabular}

pits. Accelerated decomposition and some wind displacement of mulch occurred on these highly saline sites. Irrigation resulted in limited establishment of the seeded species; however, only 4 species had produced measurable stands on the irrigated site 7 months after planting (Table 7) while no establishment of seeded species occurred on unirrigated plots. Alkali sacaton established the most uniform stands, followed by kleingrass and King Ranch bluestem. An encouraging result was the response of transplanted fourwing saltbush on these severely altered soils. Survival of fourwing saltbush transplants 7 months after planting averaged 30 and $26 \%$ on the irrigated and dryland sites, respectively, and standing crops averaged 1,049 and $948 \mathrm{~kg} / \mathrm{ha}$, respectively. Fourwing saltbush has been shown to adjust osmotic potentials and maintain positive turgor at plant water potentials lower than $-4 \mathrm{MPa}$ (Richardson and McKell 1980). Net photosynthesis has been reported in other species of Atriplex at plant water potentials lower than $-9 \mathrm{MPa}$ (White 1976).

\section{Conclusions}

Soils from reserve pits should be analyzed to determine levels of factors that might inhibit germination and establishment of seeded species prior to planning and implementation of revegetation projects. The capillary rise of soluble salts within the soil profile which may occur over time should be taken into consideration when interpreting base-line soil analyses and selecting species to be seeded.

Fourwing saltbush appears to be well adapted to soil conditions on recently covered oil well reserve pits. However, rapid establishment of the species on reserve pit soils with extremely high soluble salt concentrations may require transplanting containerized seedlings. Kochia apparently should not be seeded at rates as great as $2.2 \mathrm{~kg} / \mathrm{PLS} / \mathrm{ha}$ on reserve pits unless temporary cover is urgently needed. Planting kochia at very low seeding rates in mixtures with perennial species could be an alternate strategy. Kleingrass and alkali sacaton appear more promising than King Ranch bluestem and Lehmann lovegrass for revegetating oil well reserve pits in west Texas.

Mulching was not critical for establishing broadcast-seeded grasses, kochia, or fourwing saltbush on reserve pit soils with low-to-moderate concentrations of soluble salts. However, the practice may be beneficial in other circumstances. Seed-free mulching material should be used if at all possible.

The costs for fencing and seeding small areas such as oil well reserve pits (approximately $0.5 \mathrm{ha}$ ) may be very high relative to current land values and potential productivity of the land. However, resale value of rangeland may be enhanced if barren areas are revegetated. Small plantings of desirable shrubs such as fourwing saltbush could also substantially benefit wildlife populations, and serve as a seed source for dissemination of desirable shrub seeds onto adjacent rangeland.

\section{Literature Cited}

Adams, J.E. 1966. Influence of mulches on runoff, erosion and soil moisture depletion. Soil Sci. Soc. Amer. Proc. 30:110-114.

Behmer, D.D., and T.M. McCalla. 1963. The inhibition of seedling growth by crop residues in soil inoculated with Penicillium urticae (Bainer). Plant and Soil 18:199-206.

Bieber, G.L. 1969. Mulches for turf area. p. 108-109 In: Twenty-eighth short course on roadside development. Ohio State Univ., Columbus.

Blum, E.L. 1977. Soil survey of Sterling County, Texas. U.S.D.A. Soil Conservation Service. U.S. Gov. Printing Office, Washington, D.C.

Deeley, G.M., and L.W. Canter. 1986. Distribution of heavy metals in waste drilling fluids under conditions of changing pH. J. Environ. Qual. 15:108-112.

Dollhopf, D.J., and E.J. Depuit. 1981. Chemical amendment and irrigation effects on sodium migration and vegetation characteristics in sodic mine soils in the Northern Great Plains. p. 481-485 In:Symposium on Surface Mining Hydrology, Sedimentology and Reclamation. Univ. of Kentucky, Lexington.

Dubetz, S., R.L. Smith, and G.C. Russell. 1959. The effect of fertilizers and osmotic pressure on germination. Can. J. Soil Sci. 39:157-164.'

Fanning, C.D., and D.L. Carter. 1963. The effectiveness of a cotton bur mulch and a ridge-furrow system in reclaiming saline soils by rainfall. Soil Sci. Soc. Amer. Proc. 27:703-706.

Gould, W.L., D. Rai, and P.J. Wierenga. 1975. Problems in reclamation of coal mine spoils in New Mexico. p. 107-121. In: Mehan Wali (ed.). Practices and problems of land reclamation in western North America. Univ. North Dakota Press, Grand Forks.

Hamilton, G.J. 1972. Investigations into the reclamation of dryland saline soils. J. Soil Conserv. N.S.W. 28:191-211.

Harbert, H.P., and W.A. Berg. 1974. Vegetation stabilization of spent oil shales. Colorado State Univ. Tech. Rep. No. 4, Fort Collins.

Madison, J.H., and R.M. Hagan. 1962. Extraction of soil moisture by Merion bluegrass ( Poa pratensis L. 'Merion') turf, as affeeted by irrigation frequency, mowing height, and other cultural operations. Agron J. 54:157-160. 
McFarland, M.L. 1984. Revegetation of oilwell reserve pits in west Texas. M.S. Thesis. Texas A\&M University, College Station.

Miller, R.W., S. Hanarvar, and B. Huneaker. 1989. Effects of drilling fluids on soils and plants. I. Individual fluid components. J. Environ. Qual. 9:547-551.

Miller, R.W., and P. Pesaran. 1980. Effects of drilling fluids on soils and plants. II. Complete drilling fluid mixture. J. Environ. Qual. 9:552-556.

Nelson, D.W., S.L. Liu, and L.E. Sommers. 1984. Extractability and plant uptake of trace elements from drilling fluids. J. Environ. Qual. 13:562-566.

O'Leary, J.W. 1984. The role of halophytes in irrigated agriculture. p. 285-300. In: R.C. Staples and G.H. Toenniessen (eds.). Salinity tolerance in plants. John Wiley and Sons, New York.

Plummer, P.A. 1977. Revegetation of disturbed intermountain area sites. p. 302-339. In: J.L. Thames (ed.). Reclamation and use of disturbed land of the Southwest. Univ. of Arizona Press, Tucson.

Potter, R.L., D.N. Ueckert, J.L. Petersen, and M.L. McFarland. 1986. Germination of fourwing saltbush seeds: Interaction of temperature, osmotic potential, and pH. J. Range Manage. 39:43-46.

Rlchardson, S.G., and C.M. McKell. 1980. Water relations of Atriplex canescens as affected by the salinity and moisture percentage of processed oil shale. Agron. J. 72:946-950.

Ries, R.E. 1980. Supplemental water for the establishment of perennial vegetation on strip-mined lands. North Dakota Agr. Exp. Sta., Farm Res. 6:21-23.

Shannon, M.C. 1984. Breeding, selection and the genetics of salt tolerance. p. 231-254. In: R.C. Staples and G.H. Toenniessen (eds.). Salinity tolerance in plants. John Wiley and Sons, New York.
Simpson, J.P. 1975. Drilling fluid principles and operations. p. 463-472. In: F. Fisher (project officer). Conf. Proc., Environmental aspects of chemical use in well-drilling operations. Office of Toxic Substances, Houston, Texas.

Springfield, H.W. 1964. Factors affecting germination of fourwing saltbush. USDA Forest. Serv. Res. Note. RM-25.

Sprinffield, H.W. 1972. Using mulches to establish woody chenopods. p. 382-391. In: Wildland shrubs-their biology and utilization. July 1971, Logan, Utah. USDA Forest Serv. Gen. Tech. Rep. Int. I.

Steele, R.G.D., and J.H. Torrie. 1960. Principles and procedures of statistics. McGraw-Hill Book Company. New York.

Stroh, J.R., and B.P. Sundbert. 1971. Emergence of grass seedlings under crop residue cover. J. Range Manage. 24:226-230.

Tadmor, N.H., Y. Cohen, and Y. Harpax. 1969. Interactive effects of temperature and osmotic potential on the germination of range plants. Crop. Sci. 9:771-774.

Uresk, D.W., and T. Yamamoto. 1986. Growth of forbs, shrubs and trees on bentonite mine spoil under greenhouse conditions. J. Range Manage. 39:113-117.

U.S. Salinity Laboratory Staff. 1954. Diagnosis and improvement of saline and alkali soils. USDA Agr. Handbook No. 60.

Van Epps, G.A., and C.M. MeKell. 1983. Effect of weedy annuals on the survival and growth of transplants under arid conditions. J. Range Manage. 36:366-369.

Welch, C.D., C. Gray, D. Pennington, and M. Young. 1980. Soil testing procedures. Texas Agr. Ext. Serv. Misc. Pub.

White, R.S. 1976. Seasonal patterns of photosynthesis and respiration in Atriplex confertifolia and Ceratoides lanata. PhD. Diss. Utah State Univ., Logan.
OREGON AGRICULTURAL EXPERIMENT STATION: Oregon State University invites nominations and applications for the position of Director of Oregon Agricultural Experiment Station and Associate Dean, College of Agricultural Sciences. The Director and Associate Dean administers and leads the statewide agricultural research programs carried out in eight colleges or campus, nine branch stations and in associated research centers. The Director is a key member of the college's administrative team, together with the Dean and the Directors of Extension, Academic Programs and International Agriculture. Qualifications include a PhD degree in agriculture or related discipline and experience in agricultural research and administration. The position is a twelve month, tenured appointment at the rank of Professor. Salary will be commensurate with experience and qualifications. Position available September 1, 1987 or soon thereafter. Nominations due April 6. Resumes and names of references from interested candidates due April 15, 1987. The search will be conducted confidentially. Letters of reference will be sought only with the knowledge and consent of top candidates following screening of professional resumes. For more information contact: C.I. Weiser, Office of the Dean, College of Agricultural Sciences, Oregon State University, Corvallis, Oregon 97331-2212. (503) 754-2331.

Oregon State University is an Affirmative Action Equal Opportunity Employer and complies with Section 504 of the Rehabilitation Act of 1973. Women and minority candidates are especially encouraged to apply.

\section{Graduate Research Assistantships Department of Forestry and Range Management Washington State University}

Projects Modeling sheep production systems: Dr. David Scarnecchia, Project Leader. Computer modeling of range sheep production systems. Project will involve some field work.

Qualifications: Bachelor of Science degree in Range Science, Animal Science or related field with 3.0 minimum cumulative GPA. Applications should have some quantitative background.

Tree Physiology: Dr. John Bassman, Project Leader, Study of the physiological responses of Populus to partial defoliation.

Qualifications: Bachelor of Science degree in Forestry, Botany, or related field with emphasis on plant physiology or plant sciences or related fields with $\mathbf{3 . 0}$ minimum cumulative GPA.

Projects will include graduate research leading to a Master of Science in Forestry and Range Management from Washington State University. Positions begin August 15, 1986.

Salary: Stipends will be $\$ 6228 /$ academic year. Additional summer stipends may be available. Non-resident tution and most of resident tutition will be waived.

Application: Send resumé, transcripts and three letters of recommendations to:

Dr. Dennis LeMaster, chair

Department of Forestry and Range Management

Washington State University

Pullman, WA $99164-6410$

Phone (509) 335-6627 